\title{
Roberto Calasso, La Folie Baudelaire
}

\section{Ida Merello}

\section{(Q) OpenEdition}

\section{Journals}

\section{Edizione digitale}

URL: http://journals.openedition.org/studifrancesi/8026

DOI: 10.4000/studifrancesi.8026

ISSN: 2427-5856

\section{Editore}

Rosenberg \& Sellier

\section{Edizione cartacea}

Data di pubblicazione: 1 juillet 2009

Paginazione: 429-430

ISSN: 0039-2944

\section{Notizia bibliografica digitale}

Ida Merello, «Roberto Calasso, La Folie Baudelaire», Studi Francesi [Online], 158 (LIII | II) | 2009, online dal 30 novembre 2015, consultato il 10 janvier 2021. URL: http://journals.openedition.org/ studifrancesi/8026 ; DOI: https://doi.org/10.4000/studifrancesi.8026

Questo documento è stato generato automaticamente il 10 janvier 2021.



Studi Francesi è distribuita con Licenza Creative Commons Attribuzione - Non commerciale - Non opere derivate 4.0 Internazionale. 


\title{
Roberto Calasso, La Folie Baudelaire
}

\author{
Ida Merello
}

\section{NOTIZIA}

ROBERTO CALASSO, La Folie Baudelaire, Milano, Adelphi, 2008, pp. 425.

1 Sesto pannello della produzione dell'autore, dopo il Rosa Tiepolo, la Folie Baudelaire si addentra nel cosmo baudelairiano, in un andirivieni tra uomo e opera, secondo il principio descritto in incipit a proposito della passeggiata del poeta nei salons degli artisti: capricciosa e svagata, eppure attenta ai dettagli, che diventano spunto di riflessioni autonome. Allo stesso modo Calasso procede svagatamente ma in profondità, accostando elementi per analogia (giocando quindi con lo stesso demone di Baudelaire), soffermandosi su frammenti di vita e frammenti di opera (lettere alla madre, la poesia Le Cygne, per fare due esempi), sui gusti pittorici (l'odio per Ingres, l'amore per Delacroix) presentando l'insorgere e lo svilupparsi di quell'onda Baudelaire che ha investito non solo i contemporanei, ma ciascuno dei posteri fino a noi, diventando parte integrante della nostra percezione del mondo. 